\title{
PROTECTED AREAS IN THE FUNCTION OF SUSTAINABLE DEVELOPMENT: CASE STUDY ON THE CITY OF BELGRADE
}

\author{
Snežana Đurđić ${ }^{* 1^{*}}$ \\ "University of Belgrade - Faculty of Geography, Belgrade
}

\begin{abstract}
The transformation of autochthonous habitats and ecosystems, the spatial distribution of which overlaps the territory with developing urban settlements, leads to a permanent destruction of their ecological stability and biodiversity impoverishment. The processes of conversion and fragmentation of habitats are simultaneously following the spreading of spatial and functional urban areas, whereby it is often possible to secure the survival of remaining species and their communities only through legal protection. The existing ecological effects in the nature protection process have been analyzed on the example of the protected areas located on the territory of the City of Belgrade. At the same time, the goal of this paper includes the consideration of potentials that, together with the process of protection of natural values, can be valorized in the context of sustainable development and provision of ecosystem services due to the adequate management of protected areas.
\end{abstract}

Key words: nature protection, protected areas, Belgrade, ecosystem services.

\section{Introductory considerations}

The transformation of natural habitats and autochthonous ecosystems into urbanized settlements structures represents one of the most powerful types of natural habitat conversions that dramatically, complexly and direct-

${ }^{1}$ Corresponding author: S. Đurđić, University of Belgrade - Faculty of Geography, Studentski trg 3/III, 11,000 Belgrade, Serbia; e-mail: snezana@gef.bg.ac.rs 
ly influence the balance of ecological processes and the preservation of the biodiversity of indigenous flora, fauna and vegetation. The spatial disposition, functionality and survival of autochthonous ecosystems, as well as rare abiotical phenomena and objects, increasingly depend on anthropogenic pressures. According to the previously said, the biotical and abiotical natural values located in urban areas must be treated with specific management measures during the protection process, so that the conflicts arisen between the needs for protection and the complex and integral functioning of the urban system are harmoniously overcome.

If the biodiversity that exists in urban conditions is viewed as "the variability among living organisms from all sources and ecosystems within an area with an increased density of human-created structures in comparison to the areas surrounding it" (Bezák, Lyytimäki, 2011), then the occurances of the simultaneous phenomena of destructive transformations of autochthonous habitats and their associated living communities are also certain. Conserving biodiversity in cities is an important global issue as urban environments play a role in the conservation of local/regional species and provide a platform for urban citizens to understand the natural processes that ultimately govern global and human sustainability (Hostetler et al., 2011).

A complexity of urban systems implies so-called urban sustainability based on the three classic pillars of sustainability - economic, social and environmental sustainability. Sustainability might imply the vitality of a city as a complex system, the quality of life of its citizens, or the capacity of nature to support its composite urban functions (Basiago, 1999).

If the biodiversity degradation process in urban conditions is viewed not only as an ecological component of sustainable development but also as an economic, social and cultural value, the approach to its protection and conservation must be actualized and justified also in the context of providing ecosystem services. Starting from the basic definition of ecosystem services as benefits that population earns due to ecosystem functions (de Groot et al, 2002), it is certain that with the continuous activities of protection, revitalization and restoration of elements that secure providing ecosystem services in urban conditions, it is possible to reduce the environmental footprint and ecological debt of cities, while at the same time improving the resilience, health condition and quality of life of the urban population (Gómez-Baggethun, Barton, 2013). Consistent with the fact that cities are characterized by multifunctionality and a high degree of transformation of natural conditions caused by long-lasting anthropogenic pressures, activities aimed toward 
successful provision of ecosystem services can be seen as an extraordinary example of equal importance for creating better living and health conditions of the urban population as well as ecological connectivity of habitats, species and their communities of life (Jennings et al., 2016; Beichler et al., 2017).

On the example of creation and functioning of the protection of natural values at the territory of the City of Belgrade, the actuality and the perspectives of harmonized improvement of the development of city functions will be considered in order to improve the quality of life of inhabitants and the simultaneous formation of integral ecological corridors and the networks of protected areas that are vital for the ecosystem and the stability of biotic communities existing in conditions of continuous direct and indirect transformation of abiotic and biotic features. The dynamics and intensity of anthropogenic pressures lead to manifestation of complex urban functions and require planning and implementation of specific measures for management of protected areas. By examining those on a case of nature protection in the territory of Belgrade, the real possibilities and potentials aimed at providing non-conflicting conditions for urban sustainable development and providing ecosystem services will be highlighted.

\section{Materials and methods}

The specifics of the biodiversity and geodiversity protection in urban conditions are the subject of scientific considerations by numerous authors (Faeth et al., 2011; McDonald et al., 2013; Мијовић, 2014; Snep et al., 2015; Norton et al., 2016). When observed in their entirety in relation to the autochthonous biocenoses or biotic communities that develop in urban areas are characterized by radical changes in the composition and richness of species, population size and density of individuals. Urban biodiversity develops at least under controlled conditions, with accompanying specific measures and management activities.

The protection of nature as a legally founded and organized expert activity is the starting point on which a functional system of protection, permanent care and improvement of the natural values condition will be formed and implemented. The first legal protection of natural assets in the area of Belgrade was established in 1947 on the basis of the Law on the Protection of Cultural Monuments and Natural Rarities. The protection covered 41 trees as a rare specimen of the plant and a rare specimen of the alohtonous plant (Антонијевић et al., 2008). Today, the normative basis for protection repre- 
sents the Law on Nature Protection (Закон о заштити природе, 2009), which provides for designation of protected areas as the basic protection unit.

Table 1 - The overview of protected areas in the territory of the City of Belgrade (surface area $>1$ ha)

\begin{tabular}{|c|c|c|c|}
\hline Protected area & Area (ha) & Management status & $\begin{array}{c}\text { Year of } \\
\text { protection } \\
\text { designation }\end{array}$ \\
\hline \multicolumn{4}{|c|}{ Landscape of outstanding features } \\
\hline Kosmaj & $3,514.50$ & Srbijašume & 2005 \\
\hline Veliko ratno ostrvo & 211 & Zelenilo - Beograd & 2005 \\
\hline Avala & 489.13 & Srbijašume & 2007 \\
\hline \multicolumn{4}{|l|}{ Natural monument } \\
\hline Banjička forest & 41.58 & Zelenilo - Beograd & 1993 \\
\hline $\begin{array}{l}\text { Botanical garden } \\
\text { "Jevremovac" }\end{array}$ & 4.81 & $\begin{array}{l}\text { University of } \\
\text { Belgrade, Faculty of } \\
\text { Biology }\end{array}$ & 1995 \\
\hline Akademski Park & 1.46 & Zelenilo - Beograd & 2007 \\
\hline Pionirski Park & 3.60 & Zelenilo - Beograd & 2007 \\
\hline Topčider park & 12.83 & Zelenilo - Beograd & 2008 \\
\hline Miljakovačka Forest & 244 & Srbijašume & 2010 \\
\hline $\begin{array}{l}\text { Faculty of Forestry } \\
\text { Arboretum }\end{array}$ & 6.69 & $\begin{array}{l}\text { University of } \\
\text { Belgrade, Faculty of } \\
\text { Forestry }\end{array}$ & 2011 \\
\hline Zvezdarska Forest & 80.57 & Zelenilo - Beograd & 2013 \\
\hline Bojčinska Forest & 670.79 & Srbijašume & 2013 \\
\hline Lipovačka Forest - Dugi rt & 241.68 & Srbijašume & 2013 \\
\hline Košutnjak Forest & 265.26 & Srbijašume & 2014 \\
\hline \multicolumn{4}{|l|}{ Protected habitat } \\
\hline $\begin{array}{l}\text { Mushrooms of Ada } \\
\text { Ciganlija }\end{array}$ & 21.34 & Srbijašume & 2013 \\
\hline Veliko Blato & $293, .68$ & $\begin{array}{l}\text { NGO Carp fishpond } \\
\text { "Mika Alas" }\end{array}$ & 2016 \\
\hline
\end{tabular}

Source: www.zzps.rs

In accordance with the state of the identified and explored natural values of biodiversity and geodiversity, the degree of their degradation and endangerment, as well as the potentials for sustainable valorization of adequately protected ecosystem and spatial areas, in the territory of the City of Belgrade, besides the protected areas listed in Table 1, five natural monu- 
ments as objects of geoheritage are also under legal protection (Sea Neogene shelf Kalemegdan, Miocene shelf Tašmajdan, Senonian shelf Mašin Majdan, Loess profile in Zemun and Loess profile Kapela in Batajnica), as well as 22 individual trees or groups of trees that are protected in the status of a natural monument of botanical character (www.zzps.rs).

Natural monuments of the botanical character are mostly individuals of dendroflora which, due to their exotic origin, dimension or age (the oldest protected tree in Belgrade is Platanus acerifolia L. fam. Platanaceae, planted in Topčider back in 1831) are considered as objects protected by the Law, and are subject to protection measures and permanent care through the management process. In addition to being example of botanical rarities and thus having an essential ecological value, their impressive visual, aesthetic and ambient features, contribute to the popularization of activities aimed towards nature protection and promotion of an idea of integral environmental protection and sustainable development.

The protected areas of Belgrade today are located on the fragments of formerly widespread autochthonous habitats. The natural vegetation of the territory of Belgrade is distinguished by the mosaics of the grasses formation developed on the pedological substrate of hydrogen and chernozem soils in the north and eco-zone forest vegetation formed to the south of the Sava and Danube rivers. In riparian habitats, there are associations with dominant hygrophilic species Salix alba L. (Salicaceae) and Populus alba L. (Salicaceae), that going farther away from river flows, are being replaced with thermo-mesophilous zones of oak forests of West-Moesian subregion. Formerly widespread forests with dominant species such as Quercus cerris L. (Fagaceae), Quercus frainetto L. (Fagaceae) and Carpinus betulus L. (Corylaceae) are today often present only in various degradated forms (Jovanović, 1988; Jakovljević et al., 2008). Apart from the remaining protected fragments of autochthonous ecosystems, the formation of integral ecological corridors for numerous migratory species, as well as the improvement of climate, sanitary, aesthetic, recreational and other ecosystem services, is also facilitated by protected areas with anthropogenic origins such as Banjička and Zvezdara forests, protected park areas and other ex situ habitats with rare and representative flora specimen.

\section{Discussion}

Through previous activities aimed at the protection of natural abiotic and biotic values in Belgrade and despite their long tradition, the dynamics 
and quality of protection that would adequately correspond to the pace and trends of spatial expansion of the City, but also to the transformation of urban functions in accordance with the population increase and economic and overall social development needs were not achieved. The research results of the group of the authors (Jovanović et al., 2014), on the basis of which it has been established that at least 50 plant species was extinct from the habitats situated on the Belgrade's territory from the period of scientific work of Josif Pančić, are in line with the previously said.

Through insight into the Action Plan on the Development Strategy of the City of Belgrade until 2021 from 2017 (Стратегија развоја Града Београда стратешки циљеви, приоритети и мере одрживог развоја до 2021. године, 2017), the strategic goal defined as "sustainable, resistant and renewable city" is evident as the one of the development priorities of the largest settlement in Serbia. Among the indicators of the success of implementation of that priority, the need to increase green and protected areas by $20 \%$ until 2021 stands out. Being directed on the achievment of this goal, but above as a matter of exceptional ecological importance, it will be the designation of the site "Wintering place of little cormorant" as Protected habitat and also designation of site "Foreland of the Belgrade's Danube left bank" as Landscape of outstanding features, which will enable connection and networking of fragments of habitats for a large number of avifauna species, as well as for integral stability of their communities. Riparian forests in urban areas, as well as diverse open moist habitats, play an important role in preserving the environment of many cities that are developing on the shores of large rivers. In addition to numerous anthropogenic impacts that endanger these fragile ecosystems, the presence and spread of invasive species, as a secondary consequence, may limit their basic functioning, ecosystem services and the importance for biodiversity protection (Radovanović et al., 2017).

Simultaneously with the scientific and professional identification of the areas that have the potential to designate protection, it is necessary to develop and timely implement the planned approach to the management of protected areas in order to enable adequate realization of ecological and landscape functionality of the protected natural values. Recognizing the fact that from the 77,851 ha of the area of the City covered by the General Urban Plan 2016, as many as 10,700 ha of the territory are identified as potentially highly valuable biotopes with prominent values for the protection of habitats and species, a worthy of nature protection of international and national importance, or as nearly authotonous biotopes with highly refugial function, we conclude that despite distinct conversion of indigenous ecosystems into 
anthropogenic, a significant area in Belgrade territory still exists that can be treated as slightly altered natural and semi-natural habitats, the whose ecological resources and potentials for sustainable development promotion are neglected and insufficiently protected from uncontrolled influences and directions of land use transformation.

The management of protected areas implies responsibility in the implementation of expert measures and activities aimed towards protecting natural values. Together with the protection, development programs, plans and projects for the improvement of the state of essential natural values and their adequate sustainable use are being encouraged. Among the development activities mostly recognized as ecologically justified and balanced, as well as economically profitable due to the relatively small financial investment and real possibilities for gaining profit, are the activities for development of the selective forms of tourism (excursion tourism, ecotourism, geotourism...), which will be followed by adequately designed educational programs and programs for the popularization of protection of natural values. Analysis of the recent situation, conflicts and perspectives of the development of selective tourism in the protected areas of Belgrade have been the subject of research of numerous authors (Đurđić et al., 2011; Rašković, 2015; Малинић, 2016; Đurđić, 2017). In accordance with their results, as well as on the basis of a comparative analysis of the current planning and documentation on management of protected areas, but also the field research, it has been noticed that there is inadequate valorization (unsatisfactory in terms of expert and organizational aspects, economically unprofitable and ecologically risky) of the natural potentials of Belgrade's protected areas as a tourist resource.

It is evident that capacities of expert staff, sources of funding, as well as the motivation of managers for responsible activities to preserve the natural values of assets that are entrusted to them, are very incompatible and often also arise from the fact that the activities of protected area management are not the main activity of the manager (for example state-owned companies Srbijašume and Zelenilo - Beograd). Tendencies to involve local communities in the decision-making process related to the management of natural resources are necessary and indispensable mechanisms directed towards the simultaneous successful realization of the nature protection and socio-economic development. In order to ensure presence and durability of the active support of the local community, it is crucial to develop interactive cooperative relationships, timely and adequate education, accurate provision of information, dialogue and exchange of experiences (Đurđić, 2016; Đurđić, 2017). As responsible and active collaborators in the process of protected area management, it is neces- 
sary to include, wherever it is appropriate, the well-established expert nongovernmental organizations, and other stakeholders that will approach the realization of measures and activities of sustainable management with more enthusiasm, but also with adequate and timely response mechanisms to the detected deficiencies in protection, as opposed to the state-owned companies. Vital to the successful implementation of the protection goals is the perception and commitment of the local population to the preservation, care and maintenance of protected areas, as well as to the sustainable use of protected areas in such a way that the anthropocentric approach to the attributes of biotic and abiotic diversity also contains an essential component of conscious responsibility for survival and conservation of species, their communities and ecosystems (Shwartz et al., 2012; Sandifera et al., 2015).

\section{Concluding considerations}

The territory of Belgrade, administratively organized in 17 municipalities, covers an area of over 320,000 ha, in which, in accordance with the provisions of the Law on Nature Protection of Serbia, the protected areas of approximately $2 \%$ of the total area of the City are located. Insufficient participation of the share of the protected areas in the overall spatial coverage of Belgrade, increasing conflicts between the needs for protection of the abiotic and biotic values, as well as the direct and indirect use of resources of these environmentally important spatial and functional entities, do not indicate that the significant effects towards sustainable development have been achieved so far. Clearly outlined strategic guidelines towards the city's sustainability in the current planning and development documents are encouraging, but also give rise to fears that an overstated tendency towards the modification of poorly transformed ecosystems, such as the example of the Landscape of outstanding features "Veliko ratno ostrvo" and the Protected habitat "Veliko Blato" into attractive touristic complexes, will degrade and permanently disturb the ecological balance and authenticity of these complex ecosystems of exceptional importance for the preservation of the wetland habitats plants, the diversity of ornithofauna and integrated network stability of fragile riparial ecosystems along the Danube and Sava rivers. At the same time, the preserved forest ecosystems deeply embedded in the urban tissue of Belgrade must be protected against all types of degradation (waste disposal, illegal construction, unplanned and illegal cuttings and shrinking vegetation, afforestation with allochthonous species, uncontrolled spread of invasive species, disturbance of animals, etc.) in order to be ecologically revitalized, and the same time, their aesthetic, tourist-recreational and produc- 
tion functions are improved in accordance with the context of sustainable development and adequate provision and use of ecosystem services.

\section{Acknowledgements}

The paper is the result of the research within the project no. 176008 funded by the Ministry of Education and Science of the Republic of Serbia.

\section{References}

Basiago, A.D. (1999). Economic, social, and environmental sustainability in development theory and urban planning practice, The Environmentalist, 19, 145-161.

Beichler, S.A., Bastian. O., Haase. D., Heiland. S., Kabisch, N., \& Müller, F. (2017). Does the Ecosystem Service Concept Reach its Limits in Urban Environments?, Landscape online, 51, 1-21, doi: 10.3097/LO.201751

Bezák, P., \& Lyytimäki. J. (2011). Complexity of Urban Ecosystem Services in the Context of Global Change, Ekológia (Bratislava), 30(1), 22-35. doi:10.4149/ekol_2011_01_22

De Groot, R.S., Wilson, M., \& Boumans, R. (2002). A typology for the description, classification and valuation of ecosystem function, goods and services, Ecological Economics, 41, 393 - 408.

Đurđić, S. (2016). Značaj implementacije politike zaštite prirode usklađene sa EU standardima za lokalne zajednice u Srbiji. U Zbornik radova "Lokalna samouprava u planiranju i uređenju prostora i naselja", (pp. 53-59). Beograd: APP Srbije, Univerzitet u Beogradu - Geografski fakultet.

Đurđić, S. (2017). Pristup očuvanju prirodnih staništa u sistemu zaštite prirode Srbije, U Zbornik radova "Planska i normationa zaštita prostora $i$ životne sredine", (pp. 33-40). Beograd: APP Srbije, Univerzitet u Beogradu - Geografski fakultet.

Đurđić, S., Stojković, S., \& Šabić, D. (2011). Nature conservation in urban conditions: A case study from Belgrade, Serbia, Maejo Int. J. Sci. Technol., 5(01), 129-145, ISSN 1905-7873.

Faeth, S.H., Bang, C. \& Saari, S. (2011). Urban biodiversity: patterns and mechanisms, Annals of the New York Academy of Sciences, 1223, 69-81. doi: 10.1111/j.1749-6632.2010.05925.x

Gómez-Baggethun, E. \& Barton, D.N. (2013). Classifying and valuing ecosystem services for urban planning, Ecological Economics, 86, 235-245. 
Hostetler, M., Allen, W., \& Meurk, C. (2011). Conserving urban biodiversity? Creating green infrastructure is only the first step. Landscape Urban Plan. doi:10.1016/j.landurbplan.2011.01.011

Jakovljević, K., Lakušić, D., Vukojičić, S., Teofilović, A., \& Jovanović, S. (2008). Floristic characteristics of Višnjička kosa near Belgrade, Serbia, Arch. Biol. Sci., 60, 703-712.

Jennings, V., Larson, L., \& Yun, J. (2016). Advancing Sustainability through Urban Green Space: Cultural Ecosystem Services, Equity, and Social Determinants of Health, Int.J. Environ. Res. Public Health, 13, 196. doi:10.3390/ijerph13020196

Jovanović, S. (1988). The steppe vegetation fragments in the surroundings of Belgrade", Arch. Biol. Sci., 40, 9-10.

Jovanović, S., Stojanović, V., Lazarević, P., Jelić, I., Vukojičić, S. \& Jakovljević, K., (2014). Flora of Belgrade surroundings (Serbia) 150 years after Pančić's monograph - a comparative overview, Botanica Serbica, 38(2), 201-207.

McDonald, R.I., Marcotullio, P.J., \& Güneralp B. (2013). Urbanization and Global Trends in Biodiversity and Ecosystem Services, In: T. Elmqvist et al. (eds.), Urbanization, Biodiversity and Ecosystem Services: Challenges and Opportunities: A Global Assessment, 31-52. doi: 10.1007/978-94-007-7088-1_3,

Norton, B.A., Evans, K.L., \& Warren, P.H. (2016). Urban Biodiversity and Landscape Ecology: Patterns, Processes and Planning, Curr. Landscape. Ecol. Rep. doi: 10.1007/s40823-016-0018

Radovanović, N., Kuzmanović, N., Vukojičić, S. Lakušić, D., \& Jovanović, S. (2017). Floristic diversity, composition and invasibility of riparian habitats with Amorpha fruticosa: A case study from Belgrade (Southeast Europe), Urban Forestry \& Urban Greening, 24, 101-108.

Rašković, D. (2015). Anthropogenic impacts on the stability of the forest ecosystems in Belgrade - comparative analysis of Košutnjak forest and Zvezdarska forest, Bulletin of the Serbian Geographical Society, 95(4), 195-206.

Sandifera, P.A., Sutton-Grierb, A.E., \& Wardc, B.P. (2015). Exploring connections among nature, biodiversity, ecosystem services, and human health and well-being: Opportunities to enhance health and biodiversity conservation, Ecosystem Services, 12, 1-15.

Shwartz A, Cosquer A, Jaillon A, Piron A, Julliard R, Raymond R, Simon, L. \& Prévot-Julliard, A. (2012). Urban Biodiversity, City-Dwellers and Con- 
servation: How Does an Outdoor Activity Day Affect the Human-Nature Relationship? PLoS ONE, 7(6), e38642.

https:// doi.org/10.1371/journal.pone.0038642

Snep, R.P.H., Kooijmans, J.L., Kwak, R.G.M., Foppen, R.P.B., Parsons, H., Awasthy, M., Sierdsema, H.L.K., Marzluff, J.M., Fernandez-Juricic, E., de Laet, J., \& van Heezik, Y.M. (2015). Urban bird conservation: presenting stakeholder-specific arguments for the development of bird-friendly cities, Urban Ecosyst, doi: 10.1007/s11252-015-0442-z

Антонијевић, С., Чворовић, 3. \& Радовић, И. (2008). Управљање заштитом природних добара на подручју Града Београда, Заштита природе, 60(1-2), 39-48.

Градска управа Града Београда, Секретаријат за привреду (2017). Стратегија развоја Града Београда - стратешки изиљеви, приоритети и мере одрживог развоја до 2021. године.

Малинић, В. (2016). Урбани екотуризам као концепт оптималног развоја ПИО Велико ратно острво, Зборник радова Географског факултета Универзитета у Београду, 64, 481-501.

Мијовић, Д. (2014). Заштита геонаслеђа у граду - изазов у урбанистичком планирању, Заштита природе, 64(1), 5-10.

Народна скупштина Републике Србије (2009). Закон о заштити природе, Службени гласник РС, 36/09, 88/10, 91/10, 14/16.

Скупштина Града Београда (2016). Генерални урбанистички план Београда, Службени лист Града Београда 11/2016, 1-108. 